\title{
25. UPPER TRIASSIC CALCAREOUS NANNOPLANKTON BIOSTRATIGRAPHY, WOMBAT PLATEAU, NORTHWEST AUSTRALIA ${ }^{1}$
}

\author{
Timothy J. Bralower, ${ }^{2}$ Paul R. Bown,${ }^{3}$ and William G. Siesser ${ }^{4}$
}

\begin{abstract}
A biostratigraphic investigation has been carried out on Upper Triassic (Carnian-Rhaetian) calcareous nannofossils from Sites 759, 760, 761, and 764 drilled on the Wombat Plateau during Ocean Drilling Program Leg 122. The recovery of continuous sequences containing well-preserved nannofossils has enabled the refinement of previous taxonomy and biostratigraphy for this interval. Fossil assemblages are of two major types: previously described calcareous taxa were recovered at Sites 761 and 764; sideritic forms, which may represent diagenetic replacement of calcareous nannofossils, were observed in material from Sites 759 and 760 . These sideritic forms proved difficult to study taxonomically due to inadequate optical properties. Calcareous nannofossil assemblages in the Upper Triassic are dominated by the species Prinsiosphaera triassica. We show that the multitude of identities of this form in the light microscope are a result of selective etching on a layered structure. We propose an evolutionary lineage for the earliest known coccoliths, with Crucirhabdus primulus as the ancestor. This species gave rise to Crucirhabdus minutus and Archaeozygodiscus koessenensis. We can divide the Upper Triassic based on the first occurrences of $C$. primulus and Eoconusphaera zlambachensis in the upper Norian. Much of the late Norian and Rhaetian were intervals of slow evolution of calcareous nannofossils. However, we noted several morphometric changes in this interval which possess biostratigraphic utility: $P$. triassica increases in diameter from an average of $6 \mu \mathrm{m}$ to over $9 \mu \mathrm{m}, E$. zlambachensis evolves from a stubby to an elongated shape, and $C$. primulus increases in size. Upper Triassic assemblages from the Wombat Plateau are similar in composition and diversity to those which have been described in detail from the Alps. In both areas, nannofossiliferous sediments interfinger with massive limestones deposited in reef and periplatform environments. Stable isotopic analyses of Wombat Plateau nannofossil assemblages indicate that they thrived in open ocean conditions. Biostratigraphy allows sequence chronostratigraphic interpretation of Site 761 and supports the eustatic-chronostratigraphic framework of Haq et al. (1987).
\end{abstract}

\section{INTRODUCTION}

During the past two decades, calcareous nannofossil stratigraphy has become a routine method of dating marine, pelagic carbonates of Jurassic to Holocene age. A subject of common debate is how much further back in time this group extends, with estimates ranging from Silurian (Deflandre, 1970) to Late Triassic (Prins, 1969). Even though some of the older specimens illustrated may indeed be calcareous nannofossils, forms that have a clear evolutionary relationship to Jurassic and younger taxa did not arise until the Late Triassic (e.g., Fischer et al., 1967; Jafar, 1983; Bown, 1987a). Study of these Upper Triassic nannoplankton assemblages has been exclusively from samples obtained from Alpine areas of Austria and Germany (e.g., Posch and Stradner, 1987) and the Mediterranean region (Di Nocera and Scandone, 1977). However, taxonomic and biostratigraphic aspects of these investigations have been hampered both by the lack of continuous fossiliferous sequences and inadequate fossil preservation.

During the course of Ocean Drilling Program (ODP) Leg 122 , a transect of four sites was drilled on the Wombat Plateau

\footnotetext{
1 von Rad, U., Haq, B. U., et al., 1992. Proc. ODP, Sci. Results, 122: College Station, TX (Ocean Drilling Program).

2 Department of Geology, Florida International University, Miami, FL 33199 , U.S.A. (Current address: Department of Geology, University of North Carolina, Chapel Hill, NC 27599-3315, U.S.A.)

${ }^{3}$ Department of Geological Sciences, University College London, Gower Street, London WC1E 6BT, United Kingdom.

4 Department of Geology, Vanderbilt University, Nashville, TN 37235, U.S.A.

Editor's Note: Information discussed in this chapter was incorporated in a paper published in Marine Micropaleontology (see Bralower et al., 1991).
}

off northwest Australia. Marine sediments of Carnian-Rhaetian age (Late Triassic, approximately $210-230 \mathrm{Ma}$ ) were recovered and are the oldest marine deposits obtained by Deep Sea Drilling Project (DSDP)/ODP expeditions. Three thirdorder eustatic cycles were recovered, including a new one now also documented from the Dolomites from Italy (B. Haq, pers. comm., 1990; von Rad et al., this volume), allowing the detailed investigation of the early evolution of the calcareous nannoplankton within a continuous sequence-stratigraphic framework. Excellent preservation of assemblages has enabled a much clearer evaluation of the taxonomic affinities of particular taxa, as well as an isotopic analysis of fine fractions which has led to a clearer interpretation of environments of early diversification of the calcareous nannoplankton.

\section{MATERIAL AND METHODS}

On Leg 122, we drilled a north-south transect of sites on the Wombat Plateau, a small horst on the northeast corner of the Exmouth Plateau (Fig. 1). Four sites were drilled (759, 760,761 , and 764) and at each a thin Cenozoic and Cretaceous sequence was recovered that unconformably overlies sediments of Late Triassic (Carnian-Rhaetian) age. Sediments dip toward the north (Fig. 2) and therefore a progression of ages was encountered on this transect, becoming older toward the south (von Rad et al., 1989). We present a brief summary of the stratigraphy and sedimentology of these sites. Full documentation is given in Haq, von Rad, O'Connell, et al. (1990).

The first site, Site $759\left(16.95^{\circ} \mathrm{S}, 115.61^{\circ} \mathrm{E}\right)$, is situated in $2092 \mathrm{~m}$ of water on the Wombat Plateau. One hole (759B) was drilled, in which $308 \mathrm{~m}$ were penetrated and $130 \mathrm{~m}$ of sediment were recovered. Triassic sediments are of Carnian-Norian age. They consist of claystone, siltstone, sandstone, lime- 


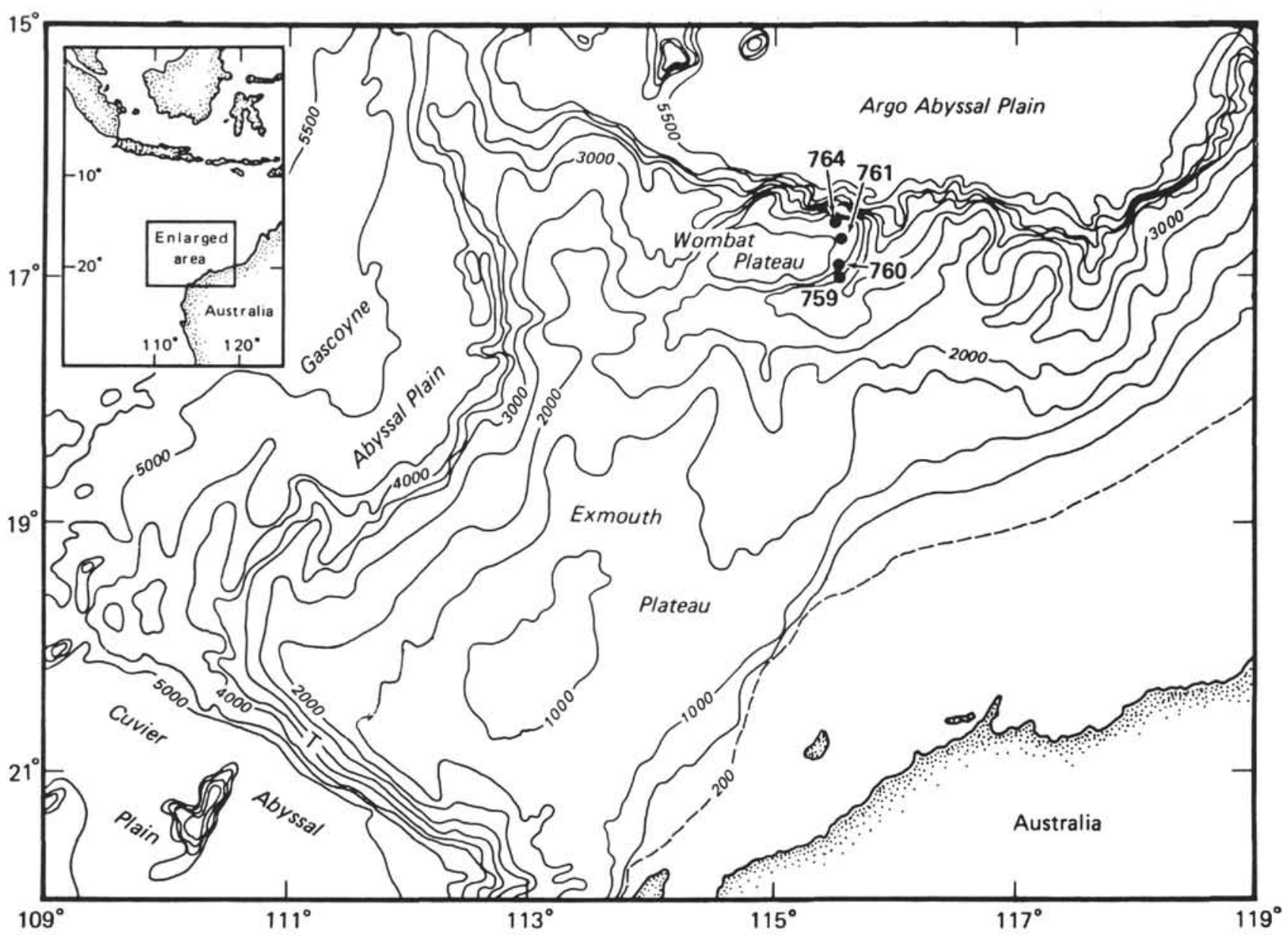

Figure 1. Location of Sites 759, 760, 761, and 764 on the Wombat Plateau off northwest Australia.

stone, and coal deposited in a range of neritic, paralic, lagoonal, deltaic, and swamp environments.

Site $760\left(16.92^{\circ} \mathrm{S}, 115.10^{\circ} \mathrm{E}\right)$ is situated $5 \mathrm{~km}$ to the north of Site 759 at a water depth of $1970 \mathrm{~m}$. Two holes $(760 \mathrm{~A}$ and 760B) were drilled. In the former, $196 \mathrm{~m}$ of $284 \mathrm{~m}$ penetrated were recovered; in the latter, $123 \mathrm{~m}$ of $506 \mathrm{~m}$ were recovered. Triassic sediments at Site 760 are Norian in age and were deposited in a range of environments similar to Site 759.

Twenty kilometers to the north of Site 760 , Site 761 $\left(16.74^{\circ} \mathrm{S}, 115.54^{\circ} \mathrm{E}\right)$ is situated in $2168 \mathrm{~m}$ of water. Two holes (761B and 761C) were drilled. In the former, $199 \mathrm{~m}$ of $287 \mathrm{~m}$ penetrated were recovered; in the latter $72 \mathrm{~m}$ of $437 \mathrm{~m}$ were recovered. One core of Triassic material was recovered in Hole 761B, whereas a thick Norian-Rhaetian section was obtained in Hole 761C. Four Triassic units were drilled in Hole $761 \mathrm{C}$. From top to bottom, these include: $79 \mathrm{~m}$ of white, shallow-water limestone of Rhaetian age; $61 \mathrm{~m}$ of interbedded crinoidal mudstone, calcareous claystone, and silty claystone deposited in environments from the littoral zone to the deep shelf; $23 \mathrm{~m}$ of dark, laminated claystone alternating with crinoidal limestone of early Rhaetian age deposited on the open shelf; and $14 \mathrm{~m}$ of black siltstone and claystone with coal of Norian age deposited in paralic, lagoonal, deltaic, and floodplain environments.

The fourth site, Site $764\left(16.57^{\circ} \mathrm{S}, 115.48^{\circ} \mathrm{E}\right)$, is situated 34 $\mathrm{km}$ to the north-northeast of Site 761 in $2699 \mathrm{~m}$ of water. Two holes (764A and 764B) were drilled. In the former $40 \mathrm{~m}$ of 69 $\mathrm{m}$ penetrated were recovered; in the latter $44 \mathrm{~m}$ of $295 \mathrm{~m}$ were obtained. The Triassic section at Hole $764 \mathrm{~A}$ overlaps the upper part of that at Hole 764B. Four Triassic sedimentary units were drilled at this site, all of Rhaetian age. From top to bottom, these include: $9 \mathrm{~m}$ of shallow-water, reefal wackestone, packstone, and grainstone; $10 \mathrm{~m}$ of recrystallized limestone and calcareous claystone deposited in lagoonal and shelf environments; $208 \mathrm{~m}$ of shallow-water limestone; and 9 $\mathrm{m}$ of dark gray, highly bioturbated calcareous claystone deposited in a restricted mudflat environment.

Upper Triassic chronostratigraphic control is provided mainly by palynology (Helby et al., 1987) and foraminiferal biostratigraphies (Zaninetti, 1976), with subsidiary information from nannofossil biostratigraphy (Jafar, 1983). The upper part of the Triassic section in Hole $761 \mathrm{C}$ belongs to the Rhaetogonyaulax rhaetica dinoflagellate Zone (Brenner, this volume, chapter 23) which is early to middle Rhaetian in age (Helby et al., 1987). A thin section from Sample 122-761C$31 \mathrm{R}-2$, 50-52 cm, contains a questionable specimen of the foraminifer Triasina hantkeni which is also indicative of Rhaetian age. Sections 122-761C-32R-CC and 122-761C$33 \mathrm{R}-\mathrm{CC}$ contain spores and pollen from the Minutosaccus crenulatus Zone of Norian age (Helby et al., 1987; Brenner, this volume, chapter 23). Pollen from the studied section in Hole 764B contain Rhaetogonyaulax rhaetica as the dominant species indicating a Rhaetian age (Helby et al., 1987; Brenner, this volume, chapter 23 ). This age is confirmed by the presence of numerous benthic foraminifers, including Triasina hantkeni, throughout the studied interval of Hole 764B.

A survey of Triassic material recovered at Sites 759, 760, 761 , and 764 was carried out aboard ship. One to three 


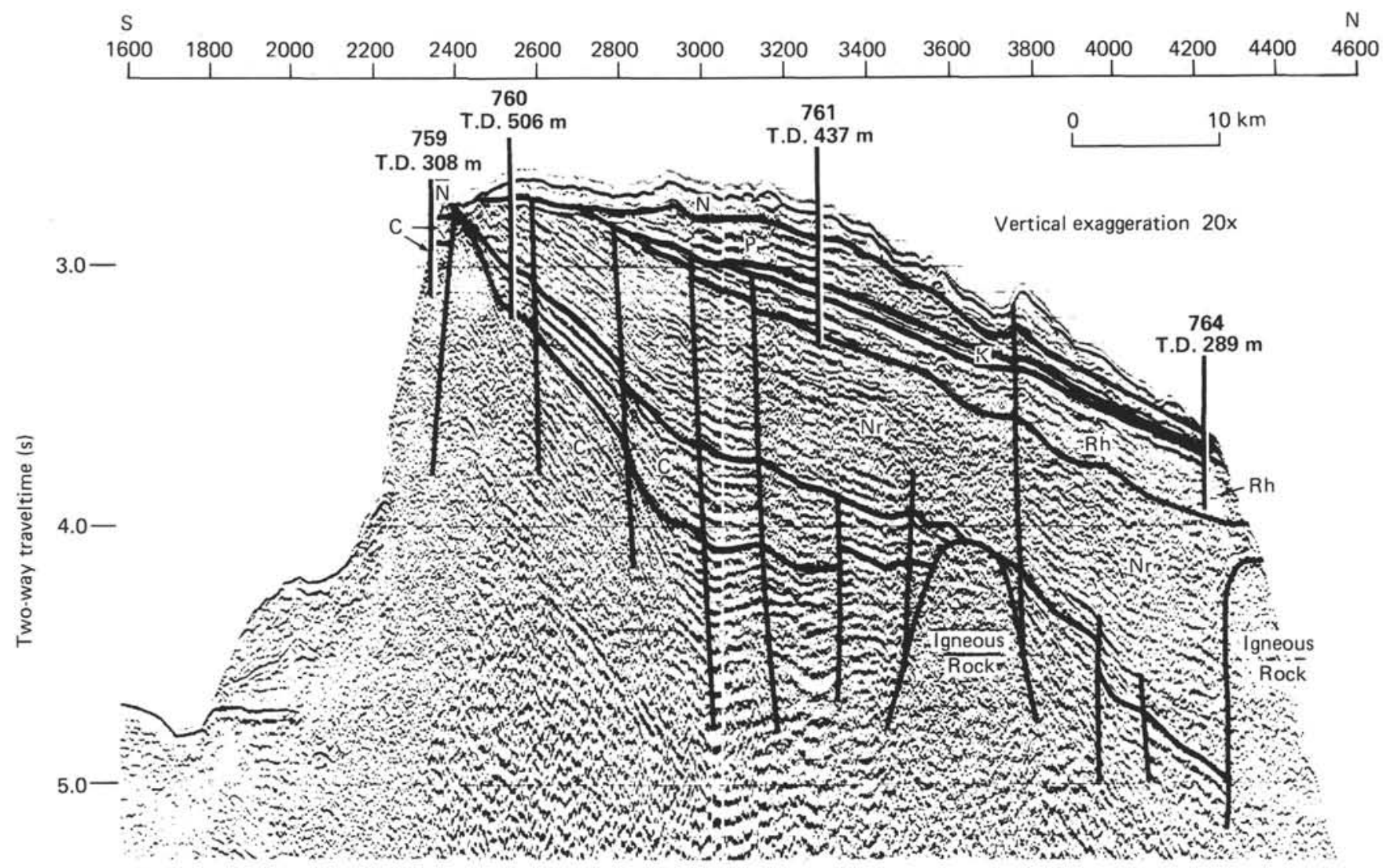

Figure 2. North-south seismic stratigraphic section through the Wombat Plateau indicating location of Sites 759, 760, 761, and 764 and approximate section recovered at each. $\mathrm{N}=$ Neogene, $\mathrm{P}=$ Paleogene, $\mathrm{K}=$ Cretaceous, $\mathrm{Rh}=\mathrm{Rhaetian}, \mathrm{Nr}=\mathrm{Norian}, \mathrm{C}=\mathrm{Carnian}$.

samples per section in fossiliferous intervals were taken for further investigation. For taxonomic purposes, we used the ISI DS-130 scanning electron microscope (SEM) at the Rosenstiel School of Marine and Atmospheric Sciences, University of Miami. This SEM is equipped with a Tracor Northern energy dispersive spectrophotometer (EDS) allowing simultaneous semiquantitative elemental analysis.

Following the taxonomic investigation, we undertook a detailed biostratigraphic study of Triassic sections from all four sites. In general, one sample per section was observed for biostratigraphic purposes, with additional samples included in critical intervals. Finally, to assist paleoenvironmental interpretation, stable carbon and oxygen isotope analyses were performed on particular bulk samples from Sites 761 and 764 . These were carried out on a Finnigan-MAT 251 mass spectrometer in the laboratory of P. Swart, Rosenstiel School of Marine and Atmospheric Sciences, University of Miami.

\section{RESULTS}

Accurate biostratigraphic analysis depends heavily on the availability of reliable and reproducible taxonomy. Our investigation suggests that some previously described Upper Triassic nannoplankton taxa are not valid, for various reasons. Composition of nannofossil assemblages varies significantly between Sites 761 and 764, where they consist of calcitic species of Prinsiosphaera and Thoracosphaera which have received prior attention, and Sites 759 and 760 , where they are composed of mostly undescribed, sideritic forms of unknown affinities.

In the case of the genus Prinsiosphaera, our investigation has led to a much better understanding of detailed ultrastructure, the variable preservation of which can lead to a myriad of identities in the light microscope (LM). Other previously reported Upper Triassic taxa, such as Hayococcus floralis (Jafar, 1983), either represent inorganic precipitates or diagenetic alteration of original nannofossils. Because of their important biostratigraphic bearing, we summarize the taxonomic results of this investigation in this section. More detailed taxonomic discussions are presented in Bralower et al. (1991).

\section{Taxonomy}

\section{Form of Prinsiosphaera triassica Jafar}

Light microscopic investigation of Prinsiosphaera has indicated a large diversity of forms (e.g., Jafar, 1983; Janofske, 1987). Our results indicate that original morphological variability has a minor control on this diversity compared to the effect of diagenetic processes such as etching and overgrowth.

The original description and classification of these taxa was by Jafar (1983), who illustrated a large variety of forms in the light microscope (see Pl. 1) and separated them into five subspecies. The subspecies were correlated with forms in the SEM, but these were almost featureless and therefore indistinguishable in this medium, as they were completely overgrown with calcite or covered with clay. A few better preserved specimens have been described by Bown (1987a) and Posch and Stradner (1987).

Using a combined LM/SEM technique on excellently preserved specimens from Holes 761C, 764A, and 764B, we describe the detailed form of Prinsiosphaera triassica and explore the great variability of this taxon in the light microscope. Our results indicate no justification for splitting this species into subspecies. We show that the large amount of 
variability observed in this taxon is a result of etching and overgrowth.

Prinsiosphaera triassica has a spherical form consisting of two separate layers (Pls. 2, 3). The thin outer layer is smooth with small buttons arranged in an irregular polygonal fashion (Pl. 2). The inner layer, which continues to the center, consists of clusters of three to ten parallel, lamellar elements (Pls. 2, 3). Neighboring clusters lie subparallel to one another. Thickness and length of individual lamellae vary greatly.

Etching affects the form of Prinsiosphaera triassica in a dramatic fashion. Typically specimens are preserved at one of four etching stages (Fig. 3). Stage 1 consists of pristine forms with an entire outer layer (e.g., Pl. 2, Fig. 1). Stage 2, a common preservational state, contains a partly etched outer layer with inner lamellar elements visible (e.g., Pl. 2, Fig. 4). In stage 3 , the entire outer layer has been stripped away but the inner layer is entire, showing the subparallel orientation of neighboring clusters (e.g., Pl. 2, Fig. 9). Finally, in stage 4, elements from the inner layer have been etched and those remaining are arranged in a somewhat random fashion (e.g., Pl. 3, Fig. 4). Specimens in stage 4 often possess small portions of preserved outer layer (e.g., Pl. 3, Fig. 2).

This preservational sequence can be observed clearly in the SEM. Its effect on LM properties is more difficult to detect mainly because the outer layer is usually thin enough to be transparent. For the same reason, calcite overgrowth or a thin coating of clay does not affect LM properties in some of our specimens, nor most of those of Jafar (1983). LM properties, however, do appear to be influenced by the width of individual calcite lamellae in the inner layer, and by a thick calcitic overgrowth and breakage or deformation. A more detailed analysis of the correlation between LM and SEM properties is given in Bralower et al. (1991).

In addition to the variation caused by preservational factors is a certain degree of diversity resulting from combined genetic and ontogenetic factors. This is apparent because size and form are variable both within an individual sample and in a stratigraphic sense. Based on preliminary measurements, the diameter of Prinsiosphaera triassica tends to increase from the Norian through the Rhaetian (see "Paleoenvironment" section, this chapter). Larger specimens appear to have proportionally thinner laths in the inner layer, and more laths within a cluster (Pl. 2, compare Figs. 7 and 8). This nondiagenetic variation can be observed in LM and SEM.

It is not possible to determine the paleobiology of Prinsiosphaera based on its fossil record. This species bears preliminary resemblance in its size and shape to contemporaneous forms of Thoracosphaera. However, significant differences are its solid structure, compared to Thoracosphaera, which is hollow, and its lack of a persistent aperture. Living Thoracosphaera is known to be a dinophyte which secretes a calcare- ous cell wall in the vegetative life phase (Tangen et al., 1982). It is possible that the cell of Prinsiosphaera was partly external to the calcitic skeleton, as opposed to Thoracosphaera, which is entirely internal.

In summary, the form of Prinsiosphaera triassica is largely related to its preservational state, most specifically with respect to the amount of etching. The species has two major layers, the preservation of which closely affects LM/SEM properties and gives rise to the diversity of forms described by Jafar (1983). Therefore, there does not appear to be a systematic way to divide this taxon.

\section{Form of Triassic Thoracosphaera}

In contrast to Prinsiosphaera triassica, Triassic members of the genus Thoracosphaera are hollow (Pl. 3, Fig. 9). The properties of $T$. geometrica and $T$. wombatensis are described in detail in Bralower et al. (1991).

\section{Thoracosphaera geometrica (Jafar)}

Specimens described by Jafar (1983) were overgrown and could not be observed in great detail. Bown (1987a) illustrated a form which was broken and subspherical in shape, probably as a result of deformation. Our study illustrates that $T$. geometrica is spherical, variable in size (3-9 $\mu \mathrm{m}$ in diameter), and individual elements are commonly overgrown to form quite large rhombs (Pl. 4, Fig. 2). Light microscopic properties of this species are very different from those of Prinsiosphaera triassica as a result of its hollow form. In cross-polarized light, this taxon often shows a clear pseudo-extinction cross. In phase contrast, the fine structure of the test can be observed and some opaque organic material commonly fills the center. This material is of likely bacterial origin.

\section{Thoracosphaera wombatensis Bralower, Bown, and Siesser}

This species has a very different shape and texture from $T$. geometrica. We have observed numerous bowl- or hat-shaped specimens between 5 and $13 \mu \mathrm{m}$ in diameter (Pl. 4, Figs. 3 and 4). These are open at the wide end, and may be valves of a bivalved structure as is the case in Schizosphaerella (Moshkovitz and Erlich, 1976). The skeleton has a coarser texture than typical Thoracosphaera or Schizosphaerella.

\section{Coccoliths}

Coccoliths of three species, Crucirhabdus primulus, $C$. minutus, and A. koessenensis were observed (PI. 4). These are all extremely small (1.5-5 $\mu \mathrm{m}$ in length). Our biostratigraphy indicates that $C$. primulus is the ancestor of a lineage which gives rise to $C$. minutus and $A$. koessenensis. This lineage is supported by development of rim structure, which is protolithic in $C$. primulus, protolithic or loxolithic in C. minutus, and loxolithic in A. koessenensis. More detailed taxonomic discussion is given in Bralower et al. (1991).

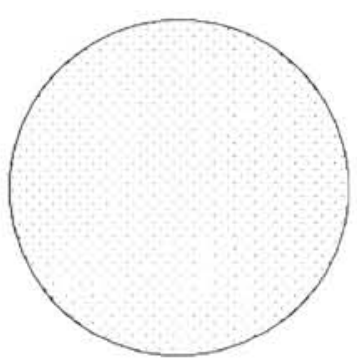

STAGE 1 ENTIRE OUTER LAYER

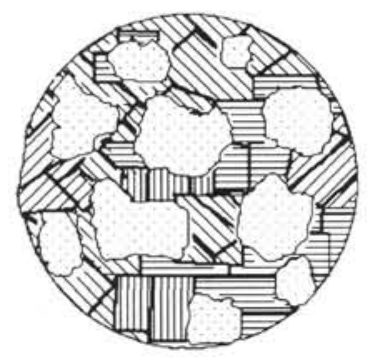

STAGE 2: PARTLY ETCHED OUTER LAYER

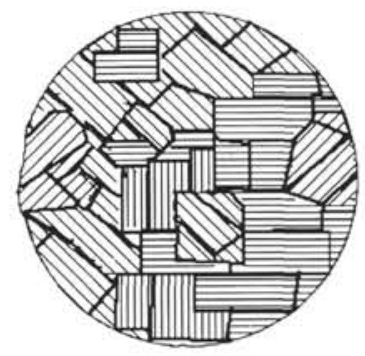

STAGE 3 ENTIRE INNER LAYER

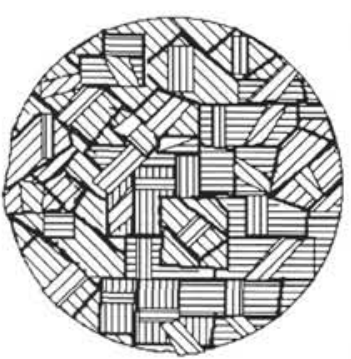

STAGE 4 ETCHED INNER LAYER

Figure 3. Four stages in the alteration of Prinsiosphaera triassica by progressive etching (see text for details). 


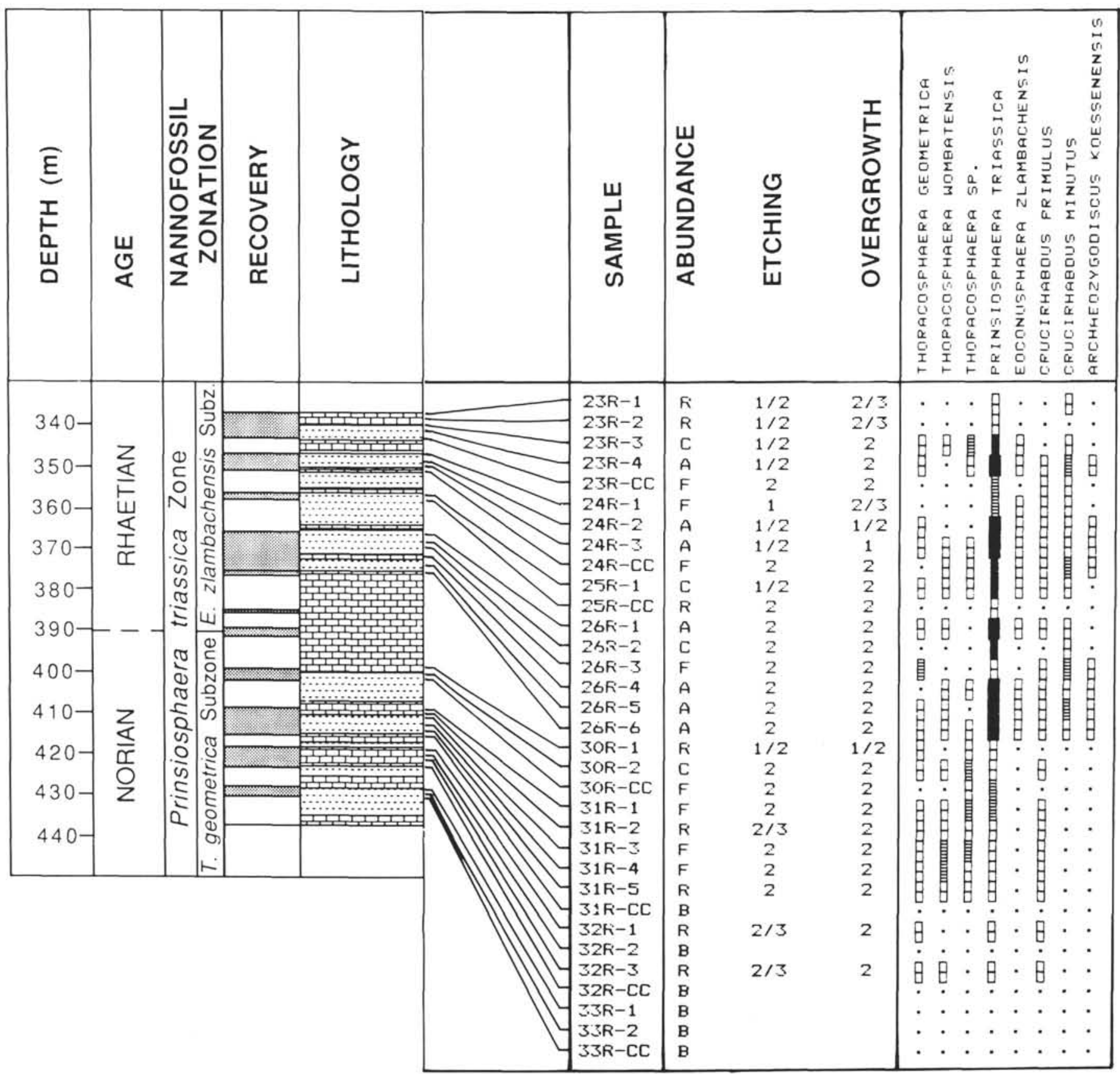

LITHOLOGY

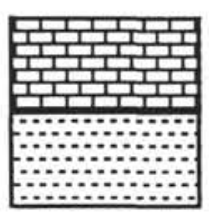

RELATIVE ABUNDANCE

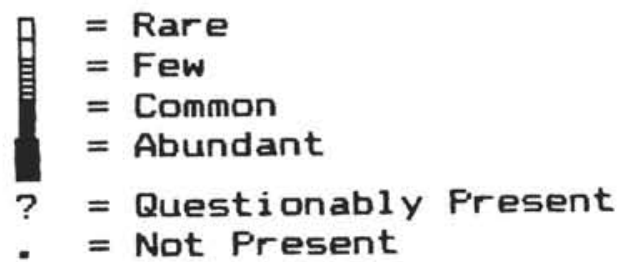

Figure 4. Calcareous nannofossil biostratigraphy of Site 761. Depth (mbsf) is shown on left side with age, nannofossil zone, recovery (recovered intervals in dark pattern), generalized lithostratigraphy, and location of samples. See text and key for explanation of sample lithology and relative species abundances. Etching and overgrowth parameters are from Roth (1978). 


\section{Sideritized Nannofossils}

An array of unusual forms were observed in Triassic sections at Sites 759 and 760 aboard ship. These possess an extremely high relief, an intricate network of elements in phase contrast, pseudo-extinction crosses in cross-polarized light, and were tentatively identified as sideritized nannofossils. The identification of this mineral has been confirmed both by combined EDS/SEM and XRD (X-ray diffraction) analyses. The latter indicates that siderite is almost pure Fe with little or no $\mathrm{Ca}, \mathrm{Mg}$, and $\mathrm{Mn}$ in solid-solution (J. Compton, pers. comm., 1990). These forms occur in variable abundance from Cores $122-759 \mathrm{~B}-25 \mathrm{R}$ to $-39 \mathrm{R}, 122-760 \mathrm{~A}-35 \mathrm{R}$ to $-37 \mathrm{R}$, and $122-760 \mathrm{~B}-25 \mathrm{R}$ to $-28 \mathrm{R}$, but diversity peaks in a few samples. The case can be made for these being alteration products of nannoplankton based on the repeated occurrence of particular shapes. One common form resembles Hayococcus floralis Jafar. Sideritization occurs during burial and methanogenesis of organic-rich sediments (Curtis, 1980) and can involve direct replacement of calcite or dolomite. We have yet to observe in the SEM any morphology bearing resemblance to a nannofossil. Awaiting the results of further investigations, we tentatively conclude that these forms represent diagenetic alteration, possibly direct replacement, of original nannofossils.

\section{BIOSTRATIGRAPHY}

Two reasonably continuous fossiliferous sections were recovered in Hole $761 \mathrm{C}$ and in the combined Holes $764 \mathrm{~A}$ and 764B. The results of this investigation add important information to the previously poorly known ranges of Upper Triassic calcareous nannofossils. In this analysis, we exclude the possible sideritized nannofossils observed in Sites 759 and 760 pending more detailed optical investigations.

Thickly concentrated smear slides were prepared so that even the rarest of occurrences could be noted. Relative abundance of nannofossils was assessed in the following fashion: a species was determined as abundant if, on average, more than 10 specimens could be observed in a field of view at $1000 \times$ magnification; common if more than one specimen could be observed in each field; few if one specimen or more could be observed in every ten fields of view; and rare if, on average, one specimen could not be observed in ten fields. Similar criteria were used to assess absolute nannofossil abundance in a sample from the total number of nannofossils per field of view. Preservation of nannofossils is moderate to good throughout the Triassic sections of Sites 761 and 764, and is described using etching and overgrowth parameters defined by Roth (1978). Special attention was paid to samples in critical stratigraphic intervals, especially toward the ends of species ranges, where slides were observed for several hours. Range charts for Sites 761 and 764 are illustrated in Figures 4 and 5 , respectively. These summarize the combined results of detailed biostratigraphic investigations by each author. We report taxa observed in one sample per section at three separate horizons.

The section recovered in Hole $761 \mathrm{C}$ is the thickest and therefore serves as the basis of our biostratigraphic investigation (Fig. 4). The uppermost events in Hole $761 \mathrm{C}$ are the first occurrences of Eoconusphaera zlambachensis, Crucirhabdus minutus, and Archaeozygodiscus koessenensis immediately above the unfossiliferous interval between Sections 122-761C26R-6 and 122-761C-30R-1. The other major taxa, including Crucirhabdus primulus, Prinsiosphaera triassica, Thoracosphaera geometrica, and Thoracosphaera wombatensis, extend to the base of the recovered section.

The Upper Triassic at Site 764 consists of a short section recovered in Hole $764 \mathrm{~A}$ that overlaps the uppermost part of the much deeper sequence recovered in Hole 764B. The nannofossiliferous section in Hole 764B is interrupted by a major reef facies between Cores $122-764 B-9 R$ and $-31 R$. The biostratigraphic results from this sequence complement those from Hole 761C (Fig. 5). E. zlambachensis, Crucirhabdus minutus, and Archaeozygodiscus koessenensis extend to the base of the section. We conclude that the first occurrence of $C$. primulus lies below those of $C$. minutus, A. koessenensis, and $E$. zlambachensis. The relative order of the latter three events could not be determined.

Even though nannofossil evolution appears to be slow through most of the Upper Triassic, and there are few stratigraphically useful nannofossil events, morphometric changes of particular taxa appear to have biostratigraphic utility. In Hole $761 \mathrm{C}$, the mean and modal diameter of Prinsiosphaera triassica steadily increases from close to $6 \mu \mathrm{m}$ in Core 122-761C-31R to over $8 \mu \mathrm{m}$ in Core 122-761C-23R (Fig. 6). The size of $P$. triassica increases from an average of 6-7 $\mu \mathrm{m}$ in Core $122-764 \mathrm{~B}-31 \mathrm{R}$ to $8-10 \mu \mathrm{m}$ in Core $122-764 \mathrm{~A}$ 5R. Eoconusphaera zlambachensis evolves from a stubby shape, which had not been previously observed, in samples close to its first occurrence (length ranging from 2 to $4 \mu \mathrm{m}$, average $3 \mu \mathrm{m}$ ) to its more usual elongated, conical form (length ranging from 3 to $6 \mu \mathrm{m}$, average $5 \mu \mathrm{m}$ ). Finally, the length of Crucirhabdus primulus tends to increase from an average of $3 \mu \mathrm{m}$ at the base of Hole $761 \mathrm{C}$ to close to $5 \mu \mathrm{m}$ at the top of Hole 764B. A synthesis of the biostratigraphic results of this investigation is illustrated in Figure 7.

\section{Zonation}

The only previous nannofossil zonation published for the Upper Triassic was that of Prins (1969), who correlated the Crucirhabdus Zone with the upper Rhaetian and Hettangian stages, but did not define it formally. Hamilton (1982) extended the lower boundary of the Annulithus arkelii Zone of Barnard and Hay (1974), defined by the first occurrence of the nominate species, from the Hettangian into the Rhaetian, but there has been no subsequent confirmation of this taxon in the Triassic. There are few known fossiliferous sequences spanning the Triassic-Jurassic boundary. Evidence suggests that the last occurrences of Prinsiosphaera triassica, Eoconusphaera zlambachensis, and Crucirhabdus minutus lie in the boundary interval (Bown and Lord, in press). Moreover, the lower Norian also appears to be unfossiliferous in the Alps and on the Wombat Plateau, and thus the first occurrences of several taxa cannot be determined. Because of the extremely high abundances of Prinsiosphaera triassica in Upper Triassic sediments, and the relative rarity and extremely small size of Crucirhabdus primulus in this interval, we prefer to use the former taxon to define a total range zone, the $P$. triassica Zone which ranges from lower Carnian to upper Rhaetian. We split this zone into two subzones based on the first occurrence of Eoconusphaera zlambachensis. The lower subzone, the Thoracosphaera geometrica Subzone, extends from the first occurrence of $\boldsymbol{P}$. triassica (lower Carnian) to the first occurrence of $E$. zlambachensis (upper Norian). The upper subzone, the $E$. zlambachensis Subzone, extends from the first occurrence of the nominate species (upper Norian) to the last occurrence of $P$. triassica (upper Rhaetian). These zones and subzones are defined formally in Bralower et al. (1991).

\section{PALEOENVIRONMENT}

\section{Assemblage Composition}

The Upper Triassic nannoplankton assemblages of the Wombat Plateau are very similar in composition to those observed in the Alpine region (Jafar, 1983; Bown, 1987a; 


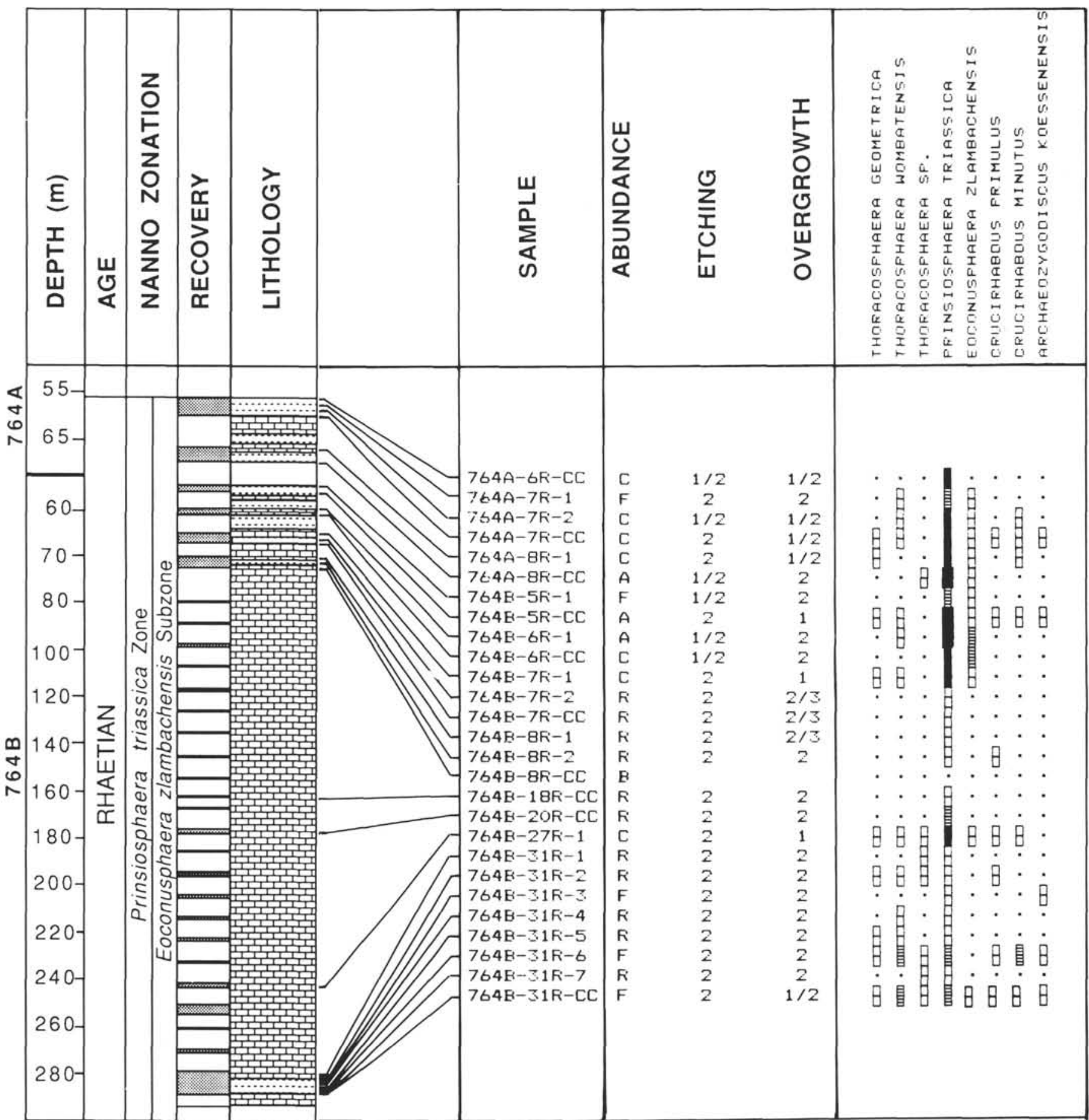

LITHOLOGY

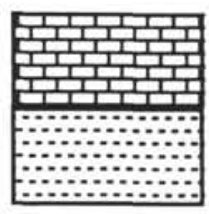

\section{RELATIVE ABUNDANCE}

\section{LIMESTONE}

CLAYSTONEMMARLSTONE

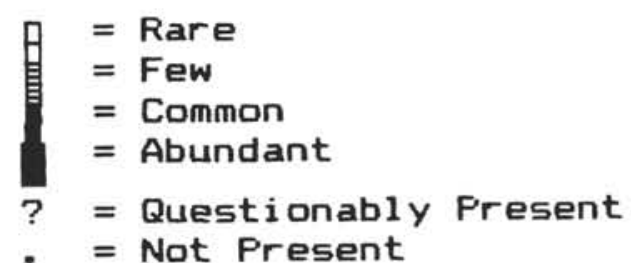

Figure 5. Calcareous nannofossil biostratigraphy of Site 764. Hole 764A is placed above Hole 764B even though the upper parts of these sections may be overlapping (see text for discussion). See explanation in Figure 4. 

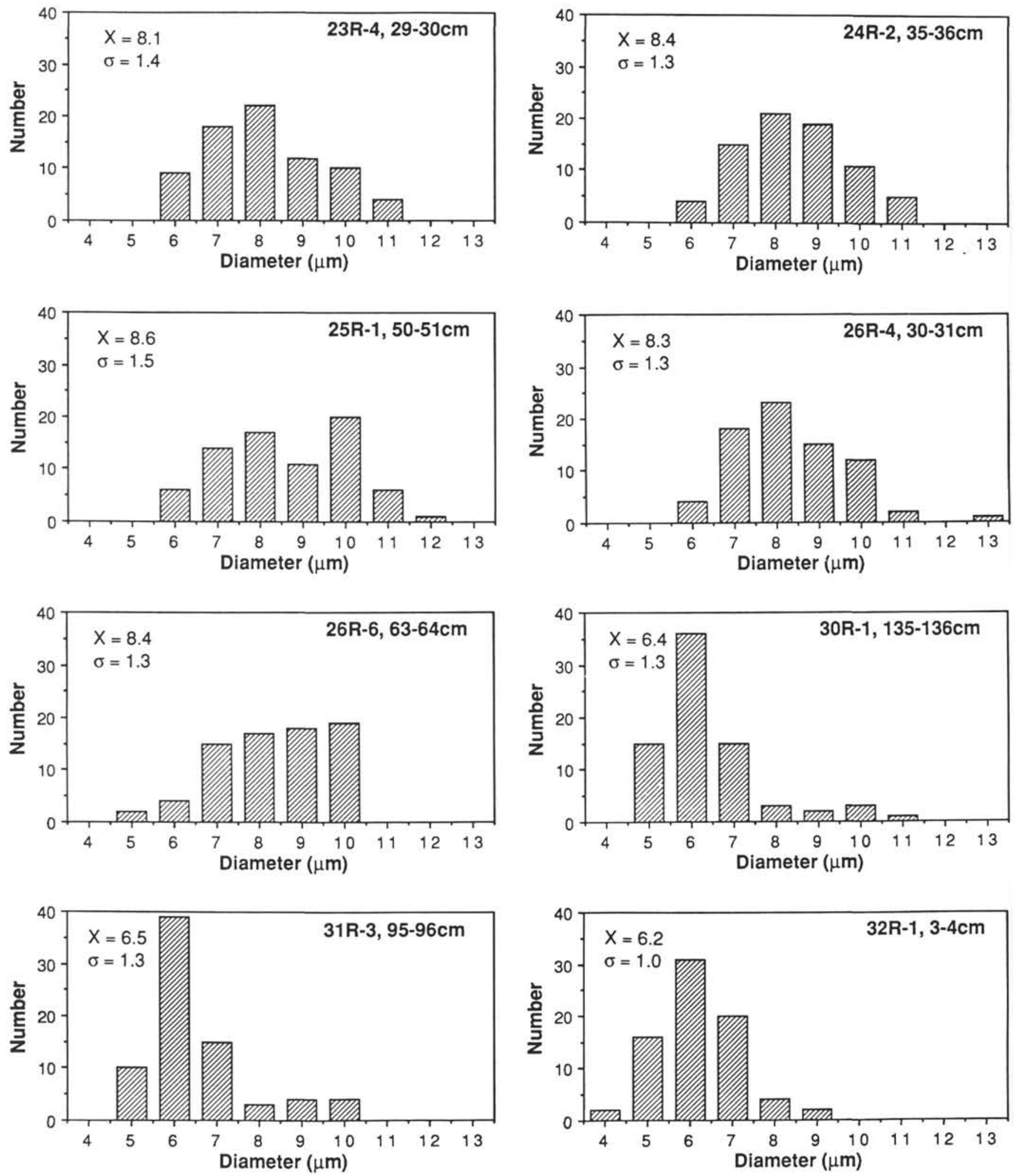

Figure 6. Biometry of Prinsiosphaera triassica from Hole 761C. Bar charts indicate frequency of diameters estimated to the nearest micron. Seventy-five specimens were measured in each sample, with mean and standard deviation of diameters shown. The data indicate an increase in size of $P$. triassica between Sections 122-761C-30R-1 and 122-761C-25R-5 of about $2 \mu \mathrm{m}$. See text for discussion. 


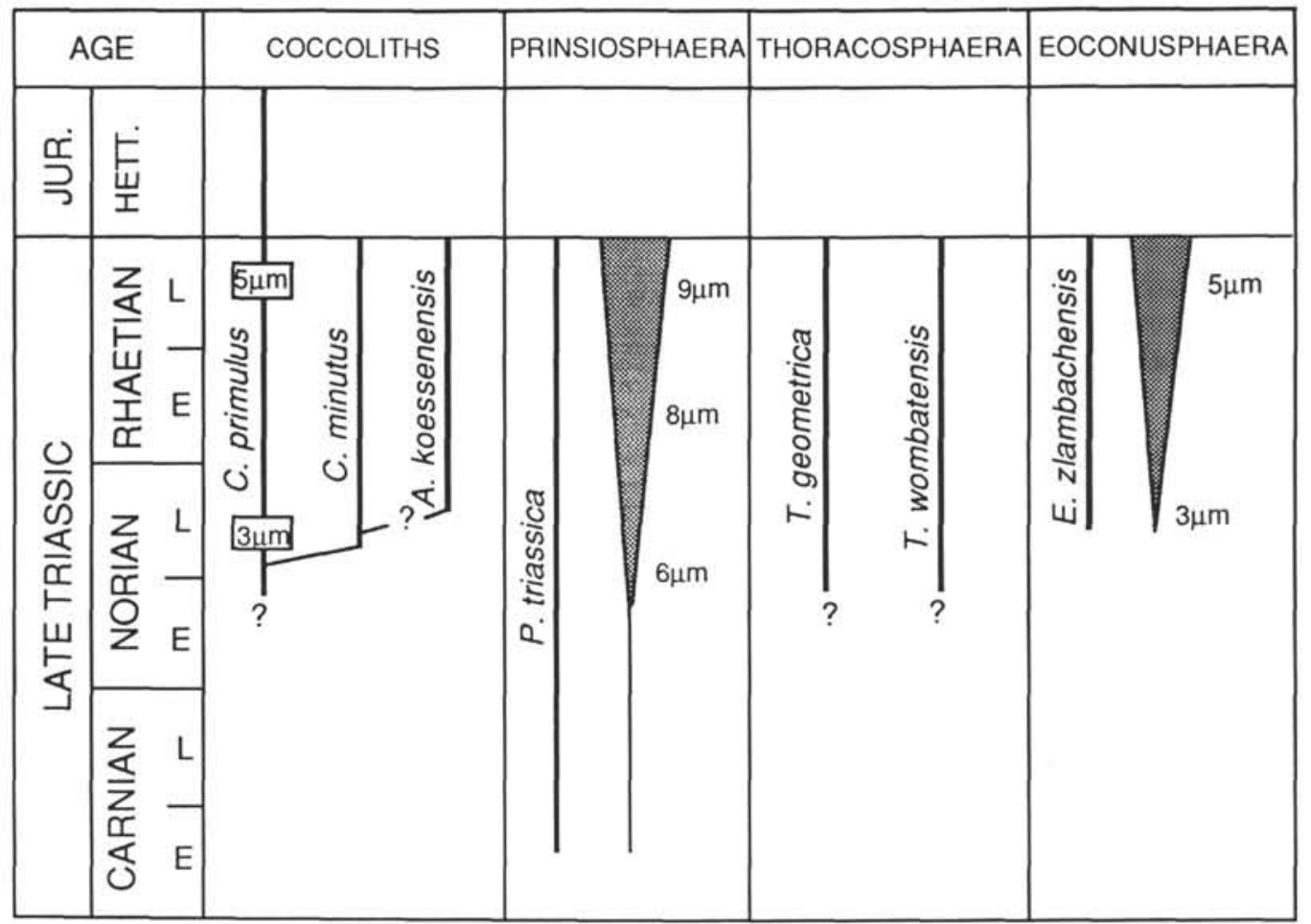

Figure 7. Stratigraphic summary of evolution of calcareous nannoplankton in the Upper Triassic. Chronostratigraphic assignments are taken from a combination of palynology, foraminiferal, and nannofossil biostratigraphy. Shaded area shows morphometric increase in average diameter of $P$. triassica and average length of $E$. zlambachensis. Average length of $C$. primulus is also included. Evolutionary ties between coccolith taxa are postulated. See text for discussion.

Janofske, 1987; Posch and Stradner, 1987). Similarities include dominance of assemblages by Prinsiosphaera triassica and lower relative abundances of coccoliths. Wombat Plateau assemblages, however, contain higher relative proportions of thoracospheres, but much lower proportions of Eoconusphaera zlambachensis. This may be a result of slightly different ages of sediments investigated in the two areas. The lack of significant assemblage differences between the two areas indicates that Upper Triassic nannoplankton had a wide distribution throughout early Neo-Tethys.

Close living relatives of Thoracosphaera, Peridinium troichoideum, and Scrippsiella sweenyae are found commonly in continental margin settings and are known to have wide salinity, temperature, and nutrient tolerances (Wall et al., 1970). Thoracosphaera is an opportunistic taxon; it quickly filled the niche vacated by the extinction of other calcareous nannoplankton species at the Cretaceous/Tertiary boundary (e.g., Thierstein, 1981). It is possible that this genus and Prinsiosphaera thrived in stressful environments in the Upper Triassic of the Wombat Plateau. Harsh conditions are indicated by the very low diversity of assemblages, the low proportions of coccoliths, and the interfingering of nannofossiliferous deposits with reef facies. The paucity of coccolithophores may alternately be because they were in the very early stages of their evolution, and the enrichment of prinsiospheres and thoracospheres may therefore be related to opportunity caused by evolution rather than by environment.

\section{Stable Isotopes}

We have conducted preliminary stable isotopic analyses of bulk sediments from Sites 761 and 764 in order to shed further light on paleoenvironment. Stable isotopes of carbon and oxygen in aragonitic and calcitic shell material have previously been used in determining paleosalinity (e.g., Dodd and Stanton, 1975). Average freshwater shows a distinctly lighter carbon isotopic signature compared to marine water because it interacts with the soil carbon reservoir which is highly negative (e.g., Hudson, 1977). Oxygen isotopic values of freshwaters are usually also lighter than those of marine waters as a result of their lowered salinity. These trends are complicated by the effects of changing temperature (e.g., Anderson and Arthur, 1983) and assemblage composition (e.g., Dudley et al., 1986) on bulk stable isotope analyses of fine-grained marine carbonates. Several authors (e.g., Dudley and Goodney, 1979; Anderson and Steinmetz, 1981; Paull and Thierstein, 1987) have illustrated the strong vital effects present in stable isotopic analyses of nannoplankton. As a result of these complications, isotopic data cannot be used to determine absolute paleosalinity, but rather to interpret broad trends such as mixing of fresh- and marine waters (e.g., Geary et al., 1989).

The results of carbon and oxygen isotopic analyses of nine bulk samples are compiled in Table 1 and plotted in Figure 8. These are compared to typical isotopic values of calcareous sedimentary rocks compiled by Hudson (1977). Our results are similar to values obtained for marine chalks, which is also closest in lithology to them. Marine limestones typically have more negative $\delta^{13} \mathrm{C}$ and $\delta^{18} \mathrm{O}$ as a result of further formation of cement, and freshwater limestones have significantly more negative $\delta^{13} \mathrm{C}$ (Fig. 8). The oxygen isotopic data obtained are similar to those from cultured or separated modern nannofossil species, but the carbon isotopic values are more positive by 1-2\%o (Dudley et al., 1986; Paull and Thierstein, 1987). The latter authors showed that samples with $>50 \%$ thoracospheres 
Table 1. Stable isotopic analyses $(\% 0$, PDB) of bulk Upper Triassic nannofossiliferous samples.

\begin{tabular}{lll}
\hline $\begin{array}{l}\text { Hole, core, section } \\
\text { interval }(\mathrm{cm})\end{array}$ & $\delta^{13} \mathrm{C}$ & ${ }^{18} \mathrm{O}$ \\
\hline 122. & & \\
& & \\
761C-24R-3, 31-34 & 2.76 & -2.17 \\
761C-26R-5, 42-43 & 1.99 & -3.05 \\
761C-30R-2, 26-27 & 2.71 & -3.05 \\
761C-31R-4, 32-34 & 1.64 & -1.82 \\
764A-7R-2, 90-92 & 2.46 & -2.98 \\
764B-5R-CC, 17-18 & 2.12 & -1.45 \\
764B-7R-2, 31-32 & 2.31 & -1.82 \\
764B-31R-6, 30-31 & 1.55 & -2.42 \\
764B-31R-CC, 13-14 & 1.25 & -2.81 \\
\hline
\end{tabular}

tend to have an average of $1 \%$ more negative $\delta^{13} \mathrm{C}$ than those composed of other nannofossil taxa. A similar vital effect in our samples, which are dominated by Prinsiosphaera triassica, would not explain their isotopic difference from Holocene nannofossils. This disparity, however, may result from the presence of diagenetic phases in the bulk sediment.

Nannofossiliferous facies from the Wombat Plateau interfinger with lagoonal and reefal facies, and were therefore deposited in fore- or back-reef environments. Nannofossilbearing sedimentary rocks from the Alps were deposited in a similar range of settings. Based on their ostracode faunas, back-reef environments are thought to have been brackish (Urlichs, 1972). However, the bulk of fossiliferous Upper Triassic samples in the Alps are from fore-reef facies. Our isotopic data indicate that the Upper Triassic nannoplankton on the Wombat Plateau also thrived in open ocean conditions.

\section{DISCUSSION}

Previous chronostratigraphic correlation of Upper Triassic calcareous nannofossil events (Jafar, 1983) indicated that Prinsiosphaera triassica ranges from lower Carnian to upper Rhaetian, and that numerous other species, including Crucirhabdus primulus, C. minutus, Archaeozygodiscus koessenensis, Eoconusphaera zlambachensis, and Thoracosphaera geometrica evolved in the upper Norian. The first occurrence of E. zlambachensis between Sections 122-761C-26R-6 and 122761C-30R-1 indicates that the Rhaetian-Norian boundary lies in, or just above, this interval, which is slightly higher than the boundary suggested by palynology. Our current biostratigraphic scheme (Fig. 7) is based on a combination of nannofossil and other chronostratigraphic ties.

Seismic stratigraphic correlation between Sites 761 and 764 is difficult as a result of the different facies represented (Exon et al., 1989). Biostratigraphic correlation is thus crucial in order to interpret sequence stratigraphic development. The nannofossiliferous sections at both Sites 761 and 764 are interrupted by intervals of massive limestone, approximately $200 \mathrm{~m}$ of reef facies in Hole 764B (Cores 122-764B-9R to $-31 \mathrm{R}$ ), and $79 \mathrm{~m}$ (Cores $122-761 \mathrm{C}-11 \mathrm{R}$ to $-23 \mathrm{R}$ ) and $23 \mathrm{~m}$ (Cores 122-761C-27R to -29R) of back-reef or lagoonal facies in Hole 761C.

Nannofossil biostratigraphy indicates that the major reefal section recovered at Site 764 is more likely to be correlative with the upper lagoonal/back-reef interval drilled at Site 761. This is indicated by the presence of Archaeozygodiscus koessenensis, Crucirhabdus minutus, and Eoconusphaera zlambachensis below the major platform interval in Hole 764B, and the upper reefal interval in Hole $761 \mathrm{C}$ but not the lower reefal interval in Hole 761C. The top of the upper back-reef/lagoonal interval in Hole $761 \mathrm{C}$ cannot be dated using nannofossils;

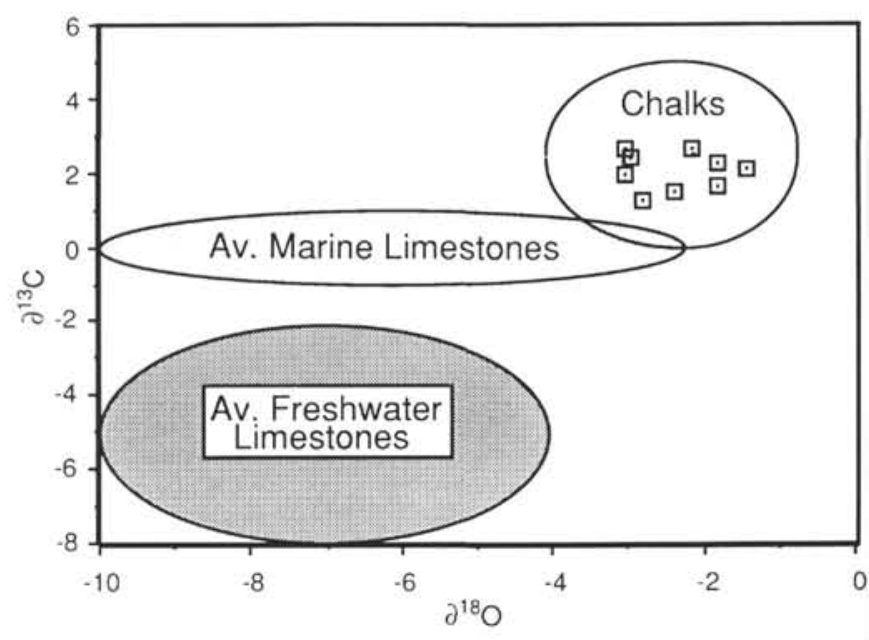

Figure 8. Carbon and oxygen isotopic measurements of bulk fossiliferous Upper Triassic samples from Sites 761 and 764 and their comparison with typical isotopic values of marine and non-marine sedimentary rocks (data from Hudson, 1977). Raw data are compiled in Table 1.

however, the base of this interval could correlate with the base of the reefal deposits in Hole 764B.

The ages of the two shallow-water limestone units at Site 761 are late Norian-early Rhaetian and late Rhaetian based on the results presented here and palynostratigraphy (Brenner, this volume, chapter 23). These correspond to lowstand intervals in the sequence chronostratigraphy of Haq et al. (1987). An additional lower Norian sequence (at $220 \mathrm{Ma}$; see von Rad et al., this volume) was also recovered, which has now also been documented in the Dolomites in Italy (B. Haq, pers. comm., 1990).

\section{CONCLUSIONS}

1. A taxonomic and biostratigraphic investigation has been carried out on Upper Triassic (Carnian-Rhaetian) calcareous nannofossils from Sites 759, 760, 761, and 764 drilled on the Wombat Plateau during ODP Leg 122.

2. Fossil assemblages are of two major types. Previously described calcareous taxa were recovered at Sites 761 and 764, and sideritic forms which may represent diagenetic replacement of calcareous nannofossils were observed in material from Sites 759 and 760 . These latter forms proved difficult to study taxonomically due to inadequate optical properties.

3. Calcareous nannofossil assemblages in the Upper Triassic are dominated by the species Prinsiosphaera triassica. We show that the multitude of identities of this form in the light microscope are a result of the effect of selective etching on a layered structure. We propose an evolutionary lineage for the earliest known coccoliths, with Crucirhabdus primulus as the ancestor. This species gives rise to Crucirhabdus minutus and A. koessenensis.

4. We can divide the Upper Triassic based on the first occurrences of $C$. primulus and Eoconusphaera zlambachensis in the upper Norian. Much of the late Norian and Rhaetian were intervals of slow evolution of calcareous nannofossils.

5 . We note several morphometric changes in this interval that possess biostratigraphic utility: $P$. triassica increases in diameter from an average of $6 \mu \mathrm{m}$ to over $9 \mu \mathrm{m}, E$. zlambachensis evolves from a stubby to an elongated shape, and C. primulus increases in size.

6. Upper Triassic assemblages from the Wombat Plateau are similar in composition and diversity to those that have 
been described in detail from the Alps. In both areas nannofossiliferous sediments interfinger with massive limestones deposited in reef and periplatform environments. Stable isotopic analyses of Wombat Plateau nannoplankton assemblages indicate that they thrived in open ocean conditions.

7. Biostratigraphy of Site 761 allows sequence chronostratigraphic interpretation and this supports the eustaticchronostratigraphic framework of Haq et al. (1987), confirming lowstand intervals in the late Norian-early Rhaetian and in the late Rhaetian.

\section{ACKNOWLEDGMENTS}

The authors acknowledge helpful discussions with W. Balch, J. Compton, B. Haq, H. Jenkyns, P. Swart, and U. von Rad. We thank J. Bergen, J. Crux, B. Haq, K. Perch-Nielsen, H. Thierstein, and D. Watkins for reviews of an earlier manuscript. We thank J. Compton (University of South Florida) and P. Swart (University of Miami) for providing XRD and stable isotopic data, respectively. We thank N. Romer, P. Blackwelder, N. Chasens, and J. Leal for assistance with SEM analysis, and J. Arfstrom and C. Botelho for laboratory and darkroom support. Research funded by USSAC (PO\#20278).

Appreciation is expressed to the editors of Marine Micropaleontology for permission to publish a large part of the information from Bralower et al. (1991) in this paper.

\section{REFERENCES}

Anderson, T. F., and Arthur, M. A., 1983. Stable isotopes of oxygen and carbon and their application to sedimentologic and paleoenvironmental problems. SEPM Short Course, 10:1-151.

Anderson, T. F., and Steinmetz, J. C., 1981. Isotopic and biostratigraphic records of calcareous nannofossils in a Pleistocene core. Nature, 294:741-744.

Barnard, T., and Hay, W. W., 1974. On Jurassic coccoliths: a tentative zonation of the Jurassic of southern England and north France. Eclogae Geol. Helv., 67:563-585.

Bown, P. R., 1985. Archaeozygodiscus-a new Triassic coccolith genus. INA Newsl., 7:32-35.

1987a. Taxonomy, evolution, and biostratigraphy of Late Triassic-Early Jurassic calcareous nannofossils. Spec. Pap. Palaeontol., 38:1-118.

1987b. The structural development of early Mesozoic coccoliths and its evolutionary and taxonomic significance. $A b h$. Geol. Bundesanst. Austria, 39:33-49.

Bown, P. R., and Lord, A. R., in press. Occurrence of calcareous nannofossils in the Triassic-Jurassic boundary interval. Cah. Inst. Cath. Lyon, Ser. Sci., II.

Bralower, T. J., Bown, P. R., and Siesser, W. G., 1991. Significance of Upper Triassic nannofossils from the southern hemisphere (ODP Leg 122, Wombat Plateau, N.W. Australia). Mar. Micropaleontol., 17:119-154.

Curtis, C. D., 1980. Diagenetic alteration in black shales. J. Geol. Soc, London, 137:189-194.

Deflandre, G., 1970. Présence de nannofossiles calcaires (coccolithes et incertae sedis) dans le Siluro-Dévonian d'Afrique du Nord. $C$. R. Seances Acad. Sci., Ser. B, 270:2916-2921.

Di Nocera, S., and Scandone, P., 1977. Triassic nannoplankton limestones of deep basin origin in the central Mediterranean region. Palaeogeogr., Palaeoclimatol., Palaeoecol., 21:101-111.

Dodd, J. R., and Stanton, R. J., 1975. Paleosalinities within a Pliocene bay, Kettleman Hills, California: a study of the resolving power of isotopic and faunal techniques. Geol. Soc. Am. Bull., 86:51-64.

Dudley, W. C., Blackwelder, P. L., Brand, L. E., and Duplessy, J. C., 1986. Stable isotopic composition of coccoliths. Mar. Micropaleontol., 10:1-8.

Dudley, W. C., and Goodney, D. E., 1979. Oxygen isotopic content of coccoliths grown in culture. Deep-Sea Res. Part A, 26:495-503.

Exon, N., Williamson, P., Haq, B., von Rad, U., and O'Connell, S., 1989. Reef play off N.W. Australia. Oil \& Gas J., Spec. Publ., 47-52.
Fischer, A. G., Honjo, S., and Garrison, R. E., 1967. Electron Micrographs of Limestones and their Nannofossils: Princeton (Princeton Univ. Press).

Geary, D. H., Rich, J., Valley, J. W., and Baker, K., 1989. Stable isotopic evidence of salinity change: influence on the evolution of melanopsid gastropods in the late Miocene Pannonian basin. Geology, 17:981-985.

Hamilton, G. B., 1982. Triassic and Jurassic calcareous nannofossils. In Lord, A. R. (Ed.), A Stratigraphic Index of Calcareous Nannofossils: Brit. Micropaleontol. Soc., Chichester (Ellis Horwood), 17-39.

Haq, B. U., Hardenbol, J., and Vail, P. R., 1987. Chronology of fluctuating sea levels since the Triassic. Science, 235:1156-1167.

Haq, B. U., von Rad, U., O'Connell, S., et al., 1990. Proc. ODP, Init. Repts., 122: College Station, TX (Ocean Drilling Program).

Helby, R., Morgan, R., and Partridge, A. D., 1987. A palynological zonation of the Australian Mesozoic. In Jell, P. A. (Ed.), Studies in Australian Mesozoic Palynology. Mem. Assoc. Australas. Palaeontol., 4:1-94.

Hudson, J. D., 1977. Stable isotopes and limestone lithification. $J$. Geol. Soc. London, 133:637-660.

Jafar, S. A., 1983. Significance of Late Triassic calcareous nannoplankton from Austria and Southern Germany. Neues Jahrb. Geol. Palaeontol. Abh., 166:218-259.

Janofske, D., 1987. Kalkige nannofossilen aus der Ober-Trias (Rhät) der Nördlichen Kalkalpen. Berl. Geowiss. Abh. Reihe A, 86:4567.

Moshkovitz, S., and Ehrlich, A., 1976. Schizosphaerella punctulata Deflandre et Dangeard and Crepidolithus crassus (Deflandre) Noël (Upper Liassic Calcareous Nannofossils from Israel and Northern Sinai), Isr. J. Earth Sci., 25:51-57.

Paull, C. K., and Thierstein, H. R., 1987. Stable isotopic fractionation among particles in Quaternary coccolith-sized deep-sea sediments. Paleoceanography, 2:423-429.

Posch, F., and Stradner, H., 1987. Report on Triassic nannoliths from Austria. Abh. Geol. Bundesanst Austria. 39:231-238.

Prins, B., 1969. Evolution and stratigraphy of coccolithinids from the Lower and Middle Lias. Proc. 1st Int. Conf. Planktonic Microfossils, Geneva, 2:547-558.

Roth, P. H., 1978. Cretaceous nannoplankton biostratigraphy and oceanography of the northwestern Atlantic Ocean. In Benson, W. E., Sheridan, R. E., et al., Init. Repts. DSDP, 44: Washington (U.S. Govt. Printing Office), 731-760.

Tangen, K., Brand, L. E., Blackwelder, P. L., and Guillard, R.R.L., 1982. Thoracosphaera heimii (Lohmann) Kamptner is a dinophyte: observations on its morphology and life cycle. Mar. Micropaleontol., 7:193-212.

Thierstein, H. R., 1981. Late Cretaceous nannoplankton and the change at the Cretaceous-Tertiary boundary. In Warme, J. E., Douglas, R. G., Winterer, E. L. (Eds.), The Deep Sea Drilling Project: A Decade of Progress: Soc. Econ. Paleontol. Mineral., Spec. Publ., 32:355-394.

Urlichs, M., 1972. Ostracoden aus den Kössener Schichten und ihre Abhängigkeit von der Ökologie. Mitt. Ges. Geol. Bergbaustud. Wien, 21:561-622.

von Rad, U., Thurow, J., Haq, B. U., Gradstein, F., Ludden, J., et al., 1989. Triassic to Cenozoic evolution of the N.W. Australian Margin and the birth of the Indian Ocean (Preliminary results of ODP Legs 122 and 123). Geol. Rundsch., 78:1189-1210.

Wall, D., Guillard, R.R.L., Dale, B., Swift, E., and Watabe, N., 1970. Calcitic resting cysts in Peridinium trochoidium (Stein) Lemmermann, an autotrophic marine dinoflagellate. Phycologia, 9:151156.

Zaninetti, L., 1976. Les Foraminiferes du Trias. Riv. Ital. Paleont., $82: 1-258$.

Date of initial receipt: 20 March 1990

Date of acceptance: 30 September 1990 Ms 122B-501 

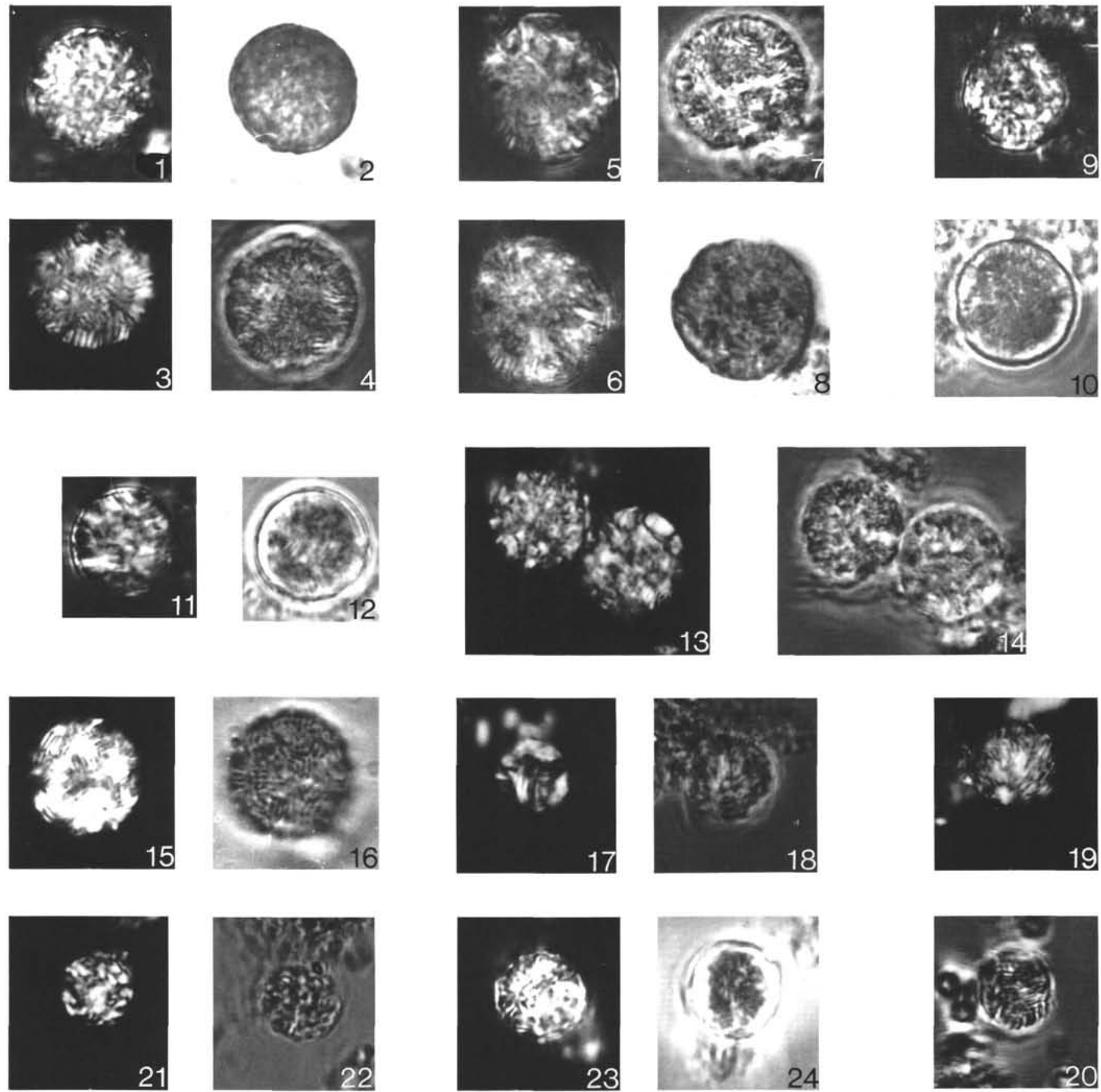

Plate 1. Prinsiosphaera triassica Jafar, 1983. 1. Cross-polarized light, Sample 122-764B-5R-CC, 17-18 cm. 2. Phase contrast, same specimen as (1). 3. Cross-polarized light, Sample $122-764 \mathrm{~B}-5 \mathrm{R}-\mathrm{CC}, 17-18 \mathrm{~cm}$. 4. Phase contrast, same specimen as (3). 5. Cross-polarized light, Sample 122-764B-5R-CC, 17-18 cm. 6. Cross-polarized light, same specimen as (5). 7. Phase contrast, same specimen as Fig. 5. 8. Bright field, same specimen as (5). 9. Cross-polarized light, Sample 122-764B-5R-CC, 17-18 cm. 10. Bright field, same specimen as (9). 11. Cross-polarized light, Sample 122-764B-5R-CC, 17-18 cm. 12. Bright field, same specimen as (11). 13. Cross-polarized light, Sample 122-764B-27R-1, 21-22 cm. 14. Phase contrast, same specimen as (13). 15. Cross-polarized light, Sample 122-764B-5R-CC, 17-18 cm. 16. Phase contrast, same specimen as (15). 17. Cross-polarized light, Sample 122-764B-27R-1, 21-22 cm. 18. Phase contrast, same specimen as (17). 19. Cross-polarized light, Sample 122-764B-27R-1, 21-22 cm. 20. Phase contrast, same specimen as (19). 21. Cross-polarized light, Sample 122-764B-27R-1, 21-22 cm. 22. Phase contrast, same specimen as (21). 23. Cross-polarized light, Sample 122-761C-24R-3, 31-34 cm. 24. Bright field, same specimen as (23). Scale: Magnification of all specimens is $2000 \times$. 

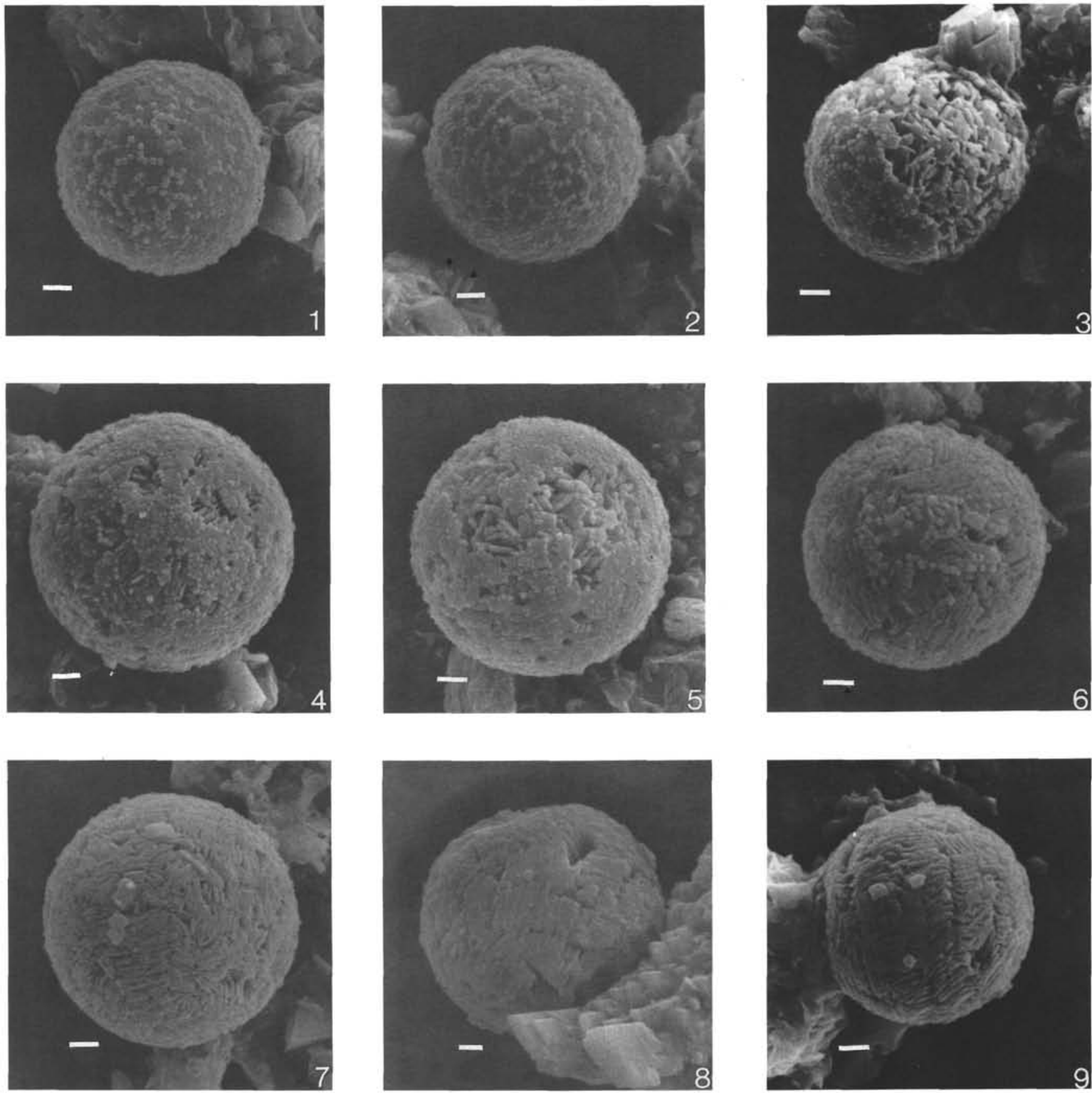

Plate 2. Prinsiosphaera triassica Jafar, 1983. 1, 2. Prinsiosphaera triassica, stage 1; (1) Scanning electron micrograph, Sample 122-764B-5R-CC, 17-18 cm; (2) scanning electron micrograph, Sample 122-764B-5R-CC, 17-18 cm. 3-6. Prinsiosphaera triassica, stage 2; (3) scanning electron micrograph, Sample 122-764B-5R-CC, 17-18 cm; (4) scanning electron micrograph, 122-764B-5R-CC, 17-18 cm; (5) scanning electron micrograph, Sample 122-764B-5R-CC, 17-18 cm; (6) scanning electron micrograph, Sample 122-764B-5R-CC, 17-18 cm. 7-9. Prinsiosphaera triassica, stage 3; (7) scanning electron micrograph, Sample 122-764B-5R-CC, 17-18 cm; (8) scanning electron micrograph, Sample 122-764B-31R-6, 30-31 cm; (9) scanning electron micrograph, Sample 122-764B-5R-CC, 17-18 cm. Scale: White bars on scanning electron micrographs represent $1 \mu \mathrm{m}$. 

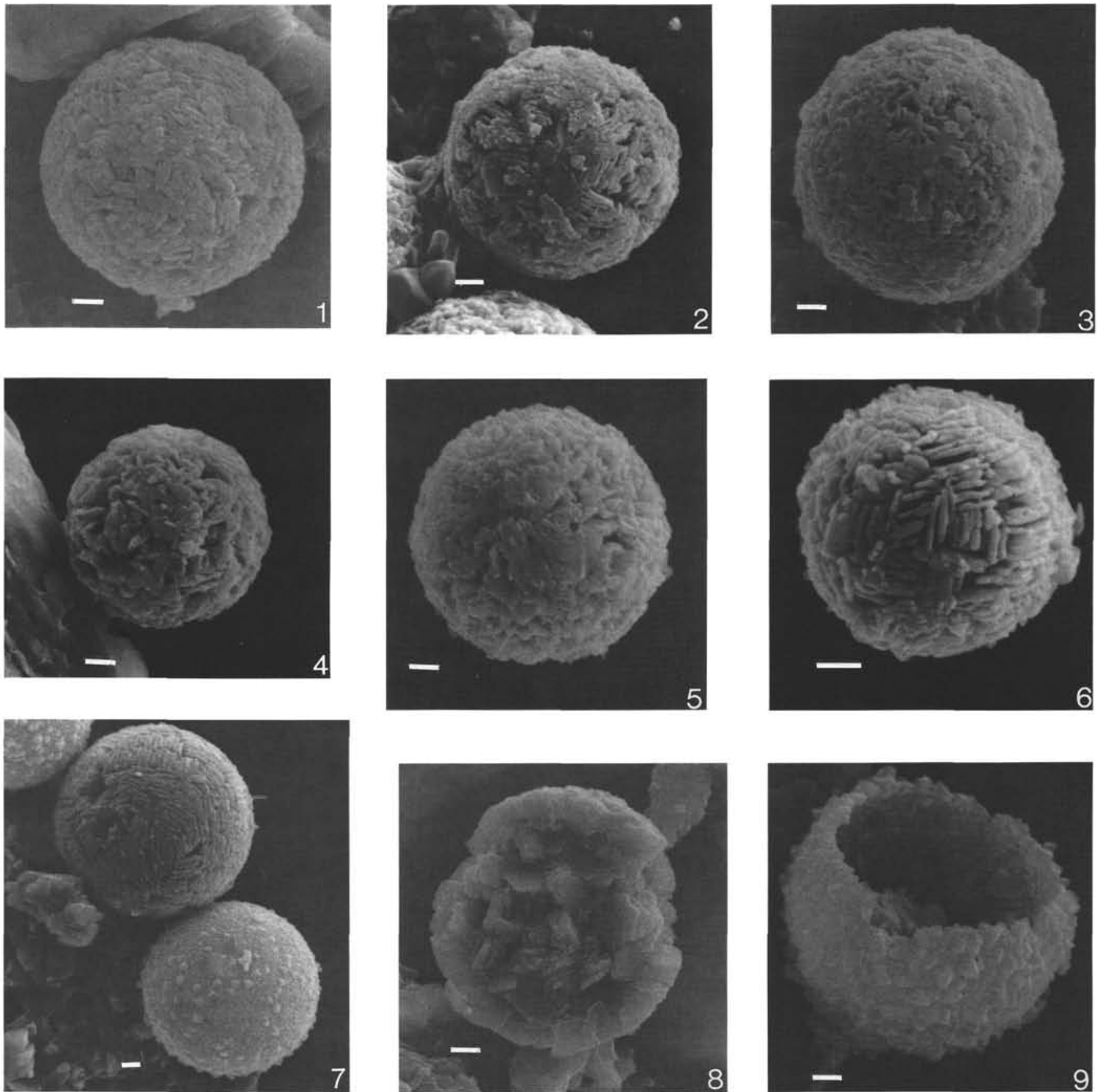

Plate 3. Prinsiosphaera triassica Jafar, 1983, and Thoracosphaera geometrica (Jafar, 1983) Bown, 1987a. 1. Prinsiosphaera triassica, stage 3; scanning electron micrograph, Sample 122-764B-5R-CC, 17-18 cm. 2-6. Prinsiosphaera triassica, stage 4. 2. Scanning electron micrograph, Sample 122-764B-5R-CC, 17-18 cm. 3. Scanning electron micrograph, Sample 122-761C-24R-3, 31-34 cm. 4. Scanning electron micrograph, Sample 122-764B-5R-CC, 17-18 cm. 5. Scanning electron micrograph, Sample 122-764B-5R-CC, 17-18 cm. 6. Scanning electron micrograph, Sample 122-764B-5R-CC, 17-18 cm. 7. Prinsiosphaera triassica Jafar, 1983, stage 3, and Thoracosphaera geometrica (Jafar, 1983) Bown, 1987a; scanning electron micrograph, Sample 122-764B-5R-CC, 17-18 cm. 8. Prinsiosphaera triassica Jafar, 1983. Ultrastructure, scanning electron micrograph, Sample 122-764B-31R-CC, 13-14 cm. 9. Thoracosphaera geometrica (Jafar, 1983) Bown, 1987a. Ultrastructure, scanning electron micrograph, Sample 122-761C-31R-4, 32-34 cm. Scale: White bars on scanning electron micrographs represent $1 \mu \mathrm{m}$. 

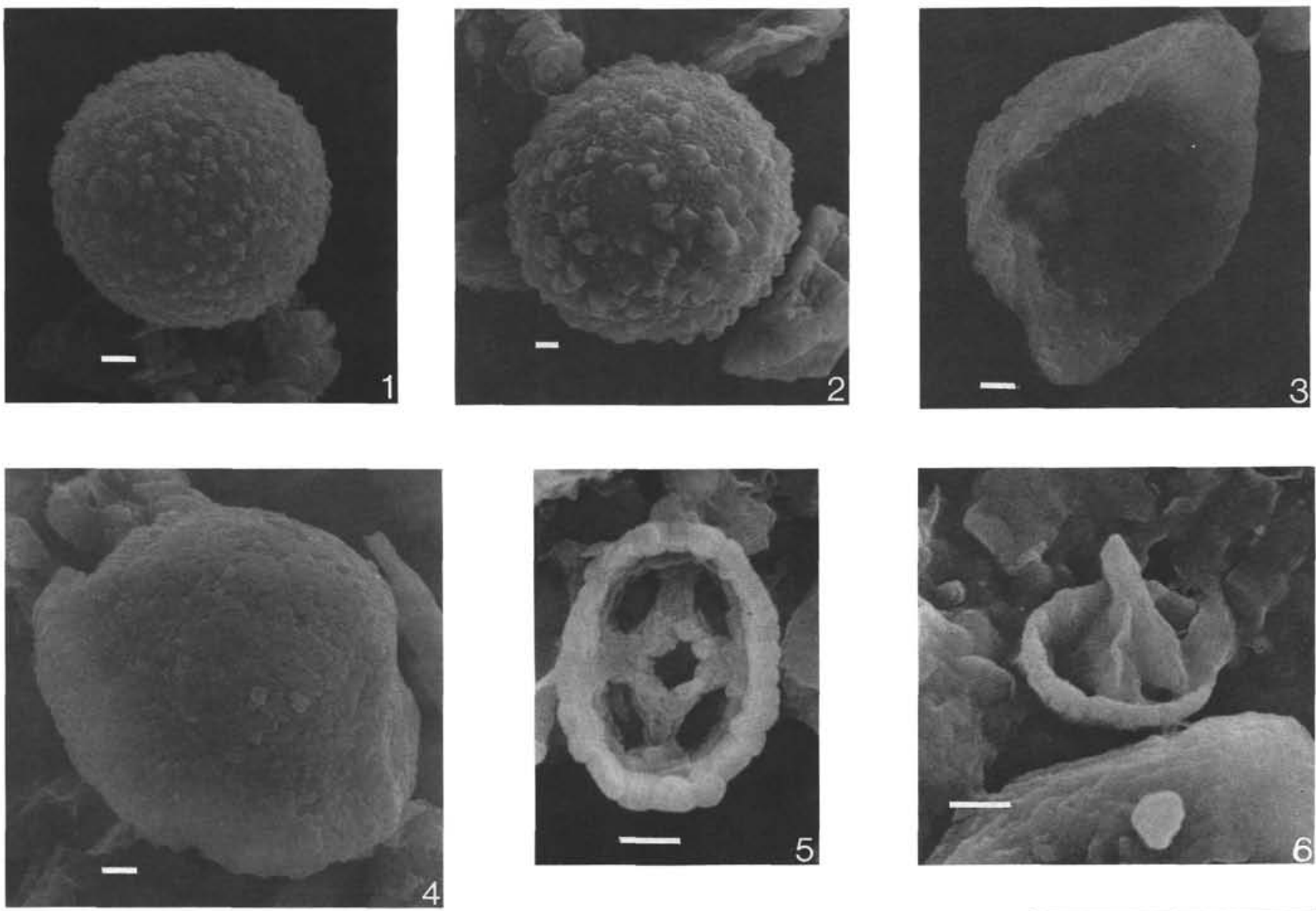

4
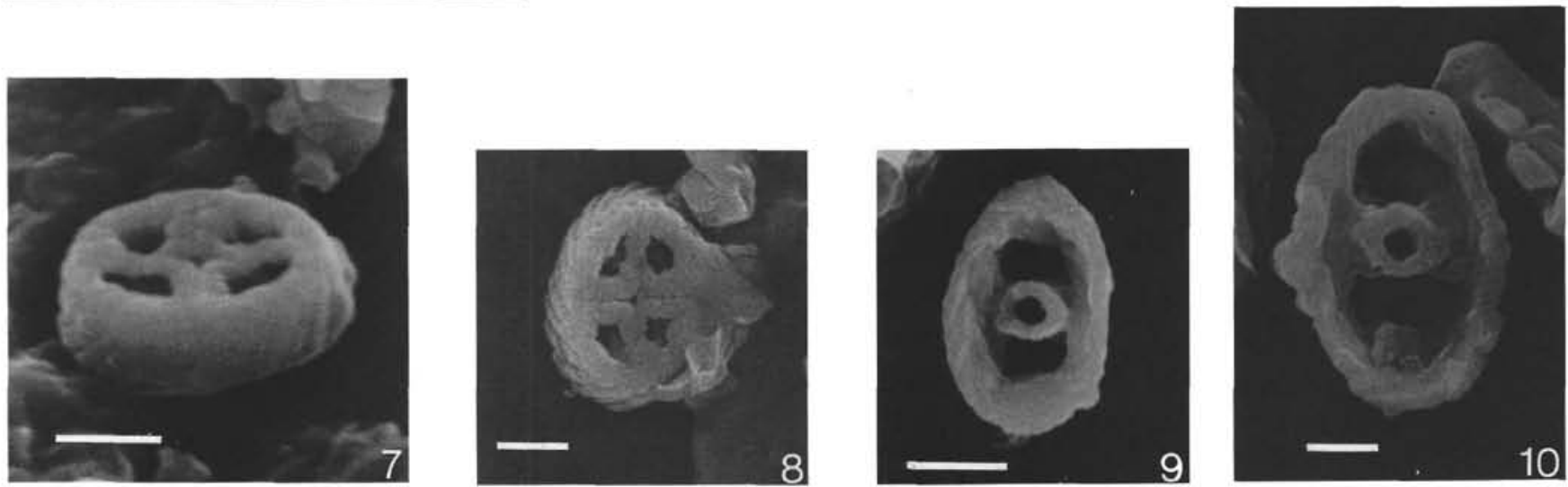

Plate 4. Assorted nannofossils. 1, 2. Thoracosphaera geometrica (Jafar, 1983) Bown, 1987a; (1) scanning electron micrograph, Sample 122-764B-5R-CC, 17-18 cm; (2) scanning electron micrograph, Sample 122-764B-31R-6, 30-31 cm. 3, 4. Thoracosphaera wombatensis Bralower, Bown, and Siesser, 1991; (3) scanning electron micrograph, Sample 122-764B-31R-CC, 13-14 cm; (4) scanning electron micrograph, Sample 122-764B-31R-CC, 13-14 cm. 5, 6. Crucirhabdus primulus (Prins, 1969, ex Rood, Hay, and Barnard, 1973) Bown, 1987a; (5) scanning electron micrograph, distal view, Sample 122-764B-5R-CC, 17-18 cm; (6) scanning electron micrograph, oblique distal view, Sample 122-761C-23R-4, 20-21 cm. 7, 8. Crucirhabdus minutus Jafar, 1983; (7) scanning electron micrograph, side view, Sample 122-761C-23R-4, 20-21 cm; (8) scanning electron micrograph, proximal view, Sample 122-761C-23R-4, 20-21 cm. 9, 10. Archaeozygodiscus koessenensis Bown, 1985; (9) scanning electron micrograph, distal view, Sample 122-761C-23R-4, 20-21 cm; (10) scanning electron micrograph, distal view, Sample 122-761C-23R-4, $20-21 \mathrm{~cm}$. Scale: White bars on scanning electron micrographs represent $1 \mu \mathrm{m}$. 